\title{
Transient cataract and hypermetropization in diabetes mellitus: case report
}

\section{Catarata transitória e hipermetropização em diabetes mellitus: relato de caso}

Fernando Trindade ${ }^{1}$

Study carried out at the Universidade Federal de Minas Gerais - UFMG - Belo Horizonte (MG) - Brazil.

${ }^{1}$ MD Universidade Federal de Minas Gerais - UFMG Belo Horizonte (MG) - Brazil.

Correspondence: Rua Manaus, 595 - Belo Horizonte (MG) CEP 30150-350

E-mail: fct@gold.com.br

Recebido para publicação em 08.05.2007

Última versão recebida em 11.05.2007

Aprovação em 15.05.2007

\begin{tabular}{|l|}
\hline ABSTRACT \\
\hline A 13-year-old male patient with a recent history of hyperglycemia \\
developed an acute bilateral posterior subcapsular cataract, consisting of \\
fine feathery streak-like opacities. On examination, his uncorrected \\
visual acuity was 20/50 and J4 at near in both eyes. Under cycloplegia, \\
a moderate hypermetropic refraction was noted in both eyes. He was \\
diagnosed with acute posterior subcapsular cataract secondary to diabe- \\
tes mellitus. Two weeks after resolution of the hyperglycemic state, the \\
bilateral feathery streak-like posterior subcapsular opacities regressed \\
completely, hypermetropic refraction decreased and uncorrected visual \\
acuity improved to $20 / 20$ and J1 in both eyes. \\
\hline
\end{tabular}

Keywords: Diabetes mellitus/complications; Cataract/etiology; Hyperopia; Case reports [Publication type]

\section{INTRODUCTION}

Acute diabetic cataracts are rare and have been infrequently reported in the literature. They often have a rapid onset, appear as fine, feathery streak-like posterior subcapsular opacities, and can resolve spontaneously. The following case report describes this condition with supportive photodocumentation.

\section{CASE REPORT}

A 13-year-old white boy recently diagnosed as type I diabetes mellitus, presented sudden vision reduction in both eyes.

His uncorrected visual acuity was 20/50 and J4 at near, in both eyes.

Under cycloplegia, his best corrected visual acuity was: OD 20/25 with $+5.00-0.50 \times 165$ and OS 20/25 with $+5.75-1.00 \times 150$.

Through a widely dilated pupil, biomicroscopic examination showed bilateral posterior subcapsular cataract consisting of various fine, feathery streak-like opacities. The feathery streaks comprised numerous tiny, round posterior subcapsular vacuoles, radiating toward the periphery (Figure 1).

The remainder of the ophthalmologic examination was normal.

Serum glucose level in the first examination was $420 \mathrm{mg} / \mathrm{ml}$ and after a period of two weeks, with efficient control and stabilization of glycemia $(89 \mathrm{mg} / \mathrm{ml})$, a complete regression of lens opacities was observed in both eyes leaving the patient with clear lenses (Figure 2).

Cataract regression was also associated with a marked reduction of hypermetropic refraction, leading to improvement of both uncorrected and best corrected visual acuity, in both eyes, as follows: UCVA 20/20 and J1 sc OU. 


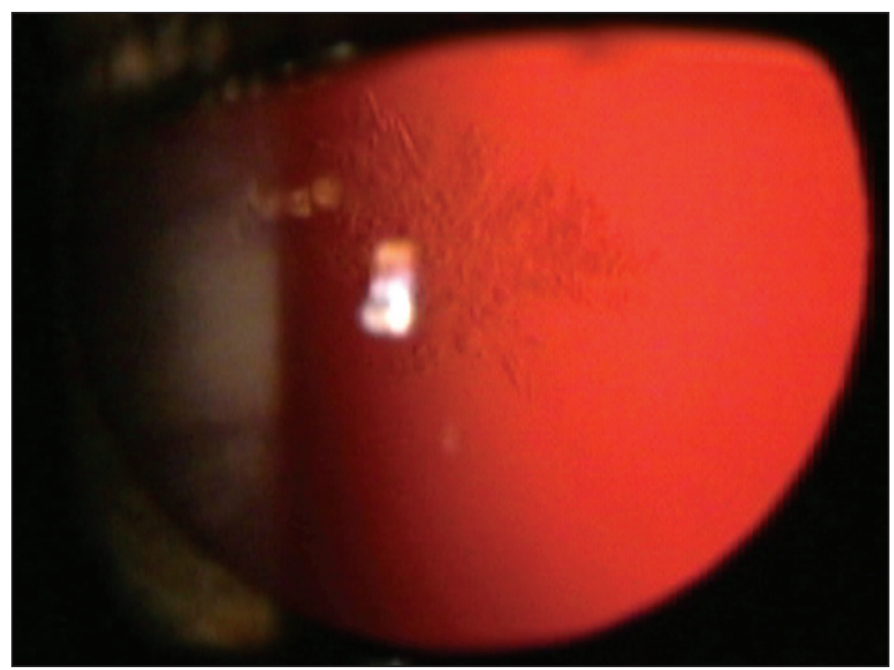

Figure 1 - Right eye: posterior subcapsular (feathery streak-like) cataract at first visit. Left eye had a similar aspect.

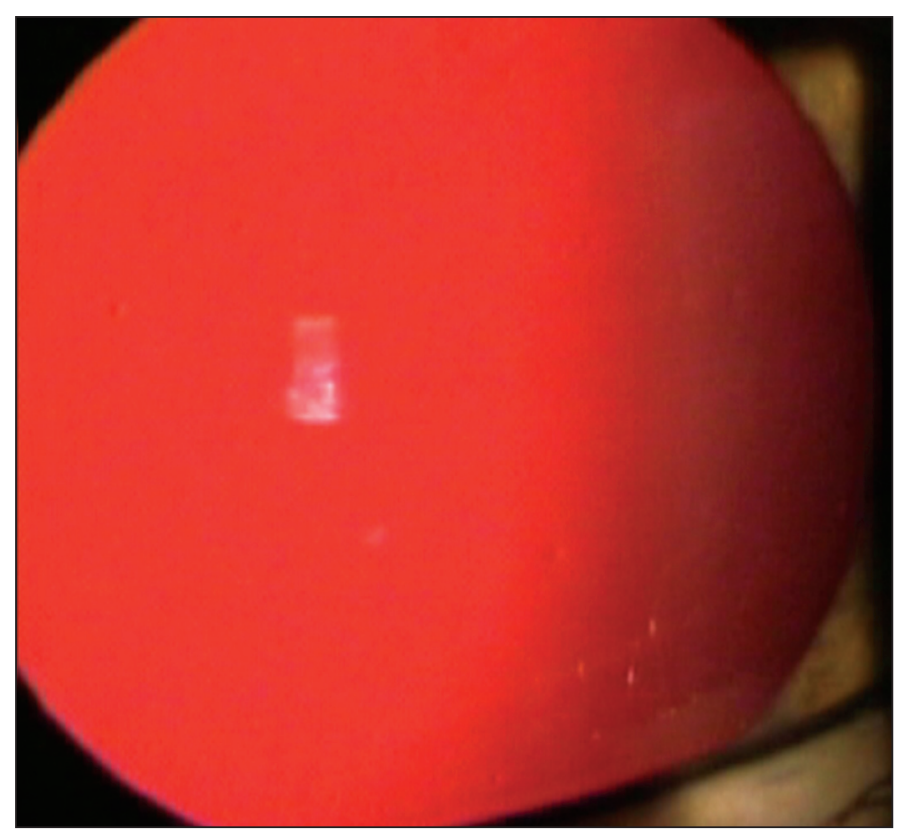

Figure 2 - Right eye: complete regression of the cataract two weeks after the first visit. Left eye had a similar appearance.

Under cycloplegia: BCVA 20/20 with +1.50 sph OU.

Therefore after glycemic control, visual symptoms improved in a short period of time leaving this young patient with clear crystalline lenses and a low bilateral latent hypermetropia.

\section{DISCUSSION}

There are some reports of transient diabetic cataracts in the literature ${ }^{(1-6)}$.

A typical diabetic cataract, which occurs preferentially in the young diabetics, is invariably bilateral, with dense white subcapsular opacities, "snowflake cataract", or fine needleshaped opacities and subcapsular vacuoles. The prevalence of the acutely developed diabetic cataract is estimated to be below $0.1 \%$ among these individuals ${ }^{(1)}$.

Transient cataract was also reported after blunt trauma, associated with hypotony after filtering procedures, in children with nephritic syndrome, and after intraoperative use of acetylcholine chloride ${ }^{(2)}$.

What strikes about this type of cataract is the rapid onset and the potential to be completely reversible. The formation of diabetic cataracts appears to be related to changes in lens hydration. The water content of the lens is about 65 percent of its total weight. Compared to other body tissues, this is relatively dry. Lens swelling also accounts for the hyperopic shift. Hence, the transient nature of diabetic cataract is related to changes in lens hydration ${ }^{(3)}$.

As a consequence of persistent hyperglycemia, sorbitol accumulates within lens fibers, thus creating an osmotic force, drawing water into the lens, leading to subcapsular vacuole formation. With the prompt control of hyperglycemia, as seen in the present case, it is postulated that lens is able to slowly metabolize its contained sorbitol and reverse the water accumulation through cellular pumping mechanisms. Since the streak-like opacities are foci of light scattering at points of water accumulation, it is readily apparent how such opacities may be reversed by eliminating excess water $^{(4)}$.

Fluctuations in the levels of aqueous humor glucose, as occurs in diabetes, cause marked changes in lens membrane permeability. The potentially reversible diabetic cataract results from an influx of water into the crystalline lens, with consequent intracellular edema and disruption of the orderly arrangement of the lens fibers altering lens transparency. Regression of acute diabetic cataract shows a centripetal pattern and is related to good plasma glucose level control. Reversibility derives from repair of new lens fibers, formation of new fibers or both mechanisms. However, cell death leads to irreversible opacification ${ }^{(2)}$.

It is believed that intracellular edema changes the transparency of normally clear lens cells, causing potential reversible opacities. However, alterations in the cell membrane permeability may lead to electrolyte and biochemical changes that cause protein denaturation and cell death, leading to irreversible lens opacification ${ }^{(5)}$.

Cases of transient hyperopia in diabetes have also been reported. Hyperopia was accompanied by lens swelling. It was suggested that transient hyperopia, with lens swelling, was caused by decreased lens refractive index following water influx. Temporary cycloplegia had no effect on refractive error ${ }^{(6)}$.

Considering the rapid onset and disappearance of this cataract, cases like the present one, have been infrequently reported.

Awareness of the potential reversibility of this type of cataract is crucial to protect patients from unnecessary surgery.

\section{RESUMO}

Paciente de 13 anos, com história recente de hiperglicemia, desenvolveu subitamente, catarata subcapsular posterior em ambos os olhos, consistindo de finas opacidades dispostas 
em forma de pena. A acuidade visual não corrigida era de 20/50 e de J4 para perto, em ambos os olhos. Sob cicloplegia, verificou-se em ambos os olhos uma moderada refração hipermetrópica. Foi, então, diagnosticado caso agudo de catarata subcapsular posterior secundária ao diabetes mellitus. Observou-se resolução total da opacidade subcapsular posterior em ambos os olhos duas semanas após regressão do quadro hiperglicêmico, assim como redução da refração hipermetrópica com melhoria da acuidade visual.

Descritores: Diabetes mellitus/complicações; Catarata/etiologia; Hiperopia; Relatos de casos [Tipo de publicação]

\section{REFERENCES}

1. Vinding T, Nielsen NV. Two cases of acutely developed cataract in diabetes mellitus. Acta Ophthalmol (Copenh). 1984;62(3):373-7.

2. Sharma P, Vasavada AR. Acute transient bilateral diabetic posterior subcapsular cataracts(1). J Cataract Refract Surg. 2001;27(5):789-94.

3. Butler PA. Reversible cataracts in diabetes mellitus. J Am Optom Assoc. 1994;65(8):559-63.

4. Epstein DL. Reversible unilateral lens opacities in a diabetic patient. Arch Ophthalmol. 1976;94(3):461-3.

5. Dickey JB, Daily MJ. Transient posterior subcapsular lens opacities in diabetes mellitus. Am J Ophthalmol. 1993;115(2):234-8.

6. Saito Y, Ohmi G, Kinoshita S, Nakamura Y, Ogawa K, Harino S, Okada M Transient hyperopia with lens swelling at initial therapy in diabetes. Br J Ophthalmol. 1993;77(3):145-8. 